\title{
Possession of prohibited images of children: three years on
}

\begin{abstract}
This article illuminates the possession element of the new offence under section 62 of the Coroners and Justice Act 2009, which outlaws certain non-photographic images of child sexual abuse. To this end, the analysis draws upon the case law concerning the offence of possession of extreme pornographic images, with which the new offence shares many common features. The article also presents the latest figures relating to convictions obtained since section 62 came into effect in April 2010. Last, it considers the proposed amendment to widen the provisions of the 2009 Act and argues that the already broad scope of the offence should be limited.
\end{abstract}

Keywords: children, prohibited images, prosecutions, convictions

\section{Background: changes in legislation}

The two principal provisions targeting indecent images of children (IIOC) in England and Wales are:

- 1. The Protection of Children Act 1978 ('PCA 1978,' 'the 1978 Act' or 'PCA'), s 1(1), which makes it an offence to take, make, distribute and show an advertisement of indecent photographs or pseudo-photographs of children. ${ }^{1}$ These offences carry a ten-year maximum prison sentence. ${ }^{2}$

- 2. The Criminal Justice Act 1988 ('CJA 1988,' 'the 1988 Act' or 'CJA'), s 160(1), which outlaws the mere possession of indecent photographs or pseudo-photographs of a child. ${ }^{3}$ This offence is punishable by up to 5 years imprisonment maximum. ${ }^{4}$

An allegation of an offence contrary to either s 1 or $s 160$ is triable either way and proceedings with respect to either offence may not be instituted without the DPP's consent.

The 1978 Act aims to prevent the involvement of children in the production of indecent photographs or films ${ }^{5}$ indirectly by criminalising the creation or distribution of such material:

\begin{abstract}
Potential damage to the child occurs when he or she is posed or pictured indecently, and whenever such an event occurs the child is being exploited. It is the demand for such material which leads to the exploitation of children and the purposes of the [1978] Act (and section 160) is to reduce, indeed as far as possible to eliminate, trade in or possession of it. ${ }^{6}$
\end{abstract}

Thus, the target is the process by which photographs are made and not the photographs themselves, which may or may not be found obscene under the Obscene Publications Act 1959 and the Obscene Publications Act $1964 .^{7}$ Additionally, possession of IIOC is deemed to increase the demand for, and consequently the production of content which necessitates the commission of a crime. ${ }^{8} \mathrm{~A}$ growing body of research shows that 'child pornographers' are 'significantly more likely than not to have sexually abused a child's and that 'there is a clear correlation between IIOC offending and contact sexual offending against children although causation cannot be established. ${ }^{10}$ Moreover, the impact of IIOC goes beyond the physical harm inflicted on a child as a result of the original abusive act: victims are faced with revictimisation every time the image is accessed, as they know that their image can be repeatedly viewed. In Beany, the Court of Appeal stated that:

\footnotetext{
the serious psychological injury which [children] would be at risk of being subjected to arises not merely from what they are being forced to do, but also from their knowledge that what they are being forced to do would be viewed by others. ${ }^{11}$
}

A child is defined as a person under the age of $18 .{ }^{12}$ In deciding whether a photograph of a child is indecent, the age is a material factor. ${ }^{13}$ It is not essential to know the identity of the child depicted: 'a person is to be taken as having been a child at any material time if it appears from the evidence as a whole that he was then under the age of [18]. ${ }^{14}$ The task of 
ascertaining the age of the person photographed is a question of fact solely for the jury to determine; expert evidence on this matter is inadmissible. ${ }^{15}$

Whether a photograph is indecent or not is also a matter for the appraisal of the jury, applying the 'recognised standards of propriety, ${ }^{16}$ as stated in Stamford. ${ }^{17}$ The circumstances in which the photographs were taken and the motivation of the taker are irrelevant in relation to this question. ${ }^{18}$ Parents will have to share Lord Woolf's confidence that 'no one could possibly suggest that a family taking photographs of their own children in the ordinary way would be a situation where it would be appropriate to prosecute'. ${ }^{19}$

The PCA was amended by the Criminal Justice and Public Order Act 1994 to meet the challenges presented by digital manipulation and special graphic software:

- 1. A new offence of 'making'20 IIOC has been inserted.

- 2. The definition of 'photograph' has been extended to include:

2a. 'data stored on a computer disc or by other electronic means which is capable of conversion into a photograph'; ${ }^{21}$ and

2b. 'pseudo-photographs,' namely images, whether made by computer-graphics or otherwise howsoever, which appear to be photographs..$^{22}$ The same change was made in S 160 of the CJA $1988 .^{23}$

Consequently, a person, who creates a photograph which appears to represent a child by digitally mapping a child's face onto the image of an adult performing a sexual act, commits an offence. The resulting photograph may be indistinguishable from a real one. In this case, no real child has been exploited in its production. It is the photograph itself here that constitutes the target, rather than the process through which it has been created. Notwithstanding the fact that no direct harm is involved, there is evidence suggesting that indecent pseudo-photographs may be used as tools for entrapment and grooming of other children. ${ }^{24}$ So, the position in England and Wales is one whereby the police believe that the creators or possessors of pseudo-photographs will end up abusing children, so the purpose of the [...] legislation may be seen as a preparatory act being criminalised'. ${ }^{25}$

Finally, statutory defences provide a framework that protects from conviction those whose possession of such material is not prurient. As explained in Land,

[...] no statutory defence is available for the individual who creates the material or advertises its availability. The defence is limited to persons who distribute or are in possession of such material either for legitimate reason [...] or for an individual who was ignorant of and had no reason to believe that he was in possession of or distributing indecent material or in the case of simple possession, those who receive it unsolicited and get rid of it with reasonable promptness. ${ }^{26}$

The 'marriage and other relationships' provisions in the PCA and CJA, inserted by the Sexual Offences Act 2003 (SOA 2003), also provide defences in circumstances where it is proved first, that the child was aged 16 or over and second, that at the relevant time the defendant and the child were married or living together in an 'enduring family relationship. ${ }^{27}$ By virtue of recent amendments, these provisions apply not only to indecent photographs of children, but also to indecent pseudo-photographs of them. ${ }^{28}$

It is worth pausing to note at this point that the abovementioned legislation targets indecent rather than obscene material ${ }^{29}$ and applies only to photographs or pseudophotographs, as well as tracings or derivatives of photographs or pseudo-photographs (discussed below). Different kinds of material, like sound, text or drawings, are covered by the general obscenity provisions under the OPA 1959. 


\section{Possession of prohibited images of children}

In 2007, the then Labour Government announced its intention to outlaw non-photographic pornographic images of children following public consultation, ${ }^{30}$ which was prompted by concerns primarily expressed by the police and children's welfare organisations over the increasing discovery of graphic depictions of child sexual abuse alongside photographs of real abuse. ${ }^{31}$ The Government of the day considered this move to be the next step in strengthening legal protection of children against conduct directly or remotely linked to sexual abuse. $^{32}$

Section 62 of the Coroners and Justice Act 2009 ('CAJA' or 'the 2009 Act') came into force on 6 Arpil 2010. It criminalises the possession of prohibited images of children (PIOC), namely computer generated child sexual abuse images, as well as manga images, private cartoons and drawings involving child sexual abuse. For the purposes of this Act, an image is defined to include not only moving but also still images and data capable of conversion into a moving or still image. ${ }^{33}$ The new offence tackles the demand for non-photographic images of child sexual abuse, which were already illegal to publish or distribute (but not to possess) in the UK under the OPA 1959. Indecent photographs or pseudo-photographs of children, tracings or derivatives of photographs or pseudo-photographs are therefore excluded. ${ }^{34}$ If a suspect is found to be in possession of IIOC, but not PIOC, prosecutors must charge that person with the offence of possession contrary to the CJA 1988. Where there is evidence that a suspect published or distributed PIOC, prosecutors should consider bringing a charge under the 1959 Act, rather than the CAJA 2009.

The offence of possession of PIOC is not retrospective and requires the DPP's consent. ${ }^{35}$ It is triable either way and is punishable by up to three years' imprisonment, ${ }^{36}$ by contrast to five years' under the $\mathrm{CJA}$, owing to the absence of a requirement for a depiction of actual abuse of a real victim. ${ }^{37}$ Offenders aged 18 or above, who have been convicted under $\mathrm{s} 62$ and have received a sentence of two years' imprisonment or more, shall be made subject to notification requirements under the SOA $2003 .{ }^{38}$

\section{The elements of the offence}

Unlike offences under the PCA and CJA, which leave the question of the 'indecent' nature of the images to the jury, ${ }^{39}$ the CAJA defines 'prohibited' images. There are three elements that must be satisfied in order for an image to fall foul of $s$ 62. The first two requirements are identical to those under s 63 of the Criminal Justice and Immigration Act 2008 (CJIA 2008), which criminalises the possession of extreme pornographic (EP) images. ${ }^{40}$

- 1. The image is pornographic, namely it is of such a nature that it must reasonably be assumed to have been produced solely or principally for the purpose of sexual arousal. ${ }^{41}$

The law requires that an image is produced for sexual arousal. This potentially widens its scope as it could cover not necessarily sexual but also violent scenes, produced for sexual purposes. The producers' intentions or the possessor's sexual arousal are irrelevant. This is a question for the judge or the jury to consider by looking at the image at issue. ${ }^{42}$ The pornography threshold should eliminate concerns that the provision may impact on valid artistic expression. The test is not intended to cover works of cultural, historic or artistic merit, or other works of public interest. ${ }^{43}$ Therefore, an express provision for a 'public good' defence similar to s 4 of the OPA 1959 is not necessary.

Where an image constitutes part of a sequence of images (for example, a graphic novel) found in the defendant's possession, its potential pornographic nature must be considered by reference to both the image itself and the context within which it is found at any given time. ${ }^{44}$ For instance, where a PIOC is part of a narrative, such as a documentary, which, if taken as a whole, may not reasonably be assumed to be pornographic, then that image will not be deemed pornographic, even if were it considered in isolation, a conclusion to the contrary would have been drawn.

This can be contrasted with the approach taken with respect to IIOC. In Murray, the appellant had recorded a documentary that showed a medical examination of a young boy. 
Through the use of motion software, he removed the doctor's commentary and edited the recording so that it focused on the manipulation of the boy's genitalia by the doctor. He was charged with 'making' an IIOC ${ }^{45}$ and submitted that he could not be guilty of the offence, given that the footage was taken from a legitimate film. The Court of Appeal found that the appellant had clearly 'made' an IIOC through his modifications and upheld the trial judge's ruling that the juries had been entitled to look at images 'independently, ${ }^{46}$ despite the fact that they had been 'abstracted' from a programme which the prosecution accepted was not indecent.

- 2. The image is grossly offensive, disgusting, or otherwise of an obscene character. ${ }^{47}$

The material must depict child sexual abuse that goes beyond the low threshold of indecency, which is appropriate where real children are, or appear to be, involved. ${ }^{48}$ In order to reflect this difference, the CAJA adopts the higher standard of obscenity. The words 'grossly offensive, disgusting, or otherwise of an obscene character' should not be read as separate concepts. They are examples of the broader concept of 'an obscene character' and not alternatives to it. Additionally, the ordinary dictionary definition of 'obscene' applies here. ${ }^{49}$

- 3. The image focuses solely or principally on a child's genitals or anal region or portrays any of the acts set out in s 62(7). These are:

a) the performance by a person of an act of intercourse or oral sex with or in the presence of a child;

b) an act of masturbation by, of, involving or in the presence of a child;

c) an act which involves penetration of the vagina or anus of a child with a part of a person's body or with anything else;

d) an act of penetration, in the presence of a child, of the vagina or anus of a person with a part of a person's body or with anything else;

e) the performance by a child of an act of intercourse or oral sex with an animal (whether dead or alive or imaginary);

f) the performance by a person of an act of intercourse or oral sex with an animal (whether dead or alive or imaginary) in the presence of a child.

Similar to the PCA and CJA, a child is a person under the age of $18 .^{50} \mathrm{An}$ image is to be treated as an 'image of a child' if the 'impression conveyed' by the image is that the person shown is a child, or the 'predominant impression conveyed' is that the person depicted is a child, even if some of the physical characteristics shown are not those of a child. ${ }^{51}$ This ensures that offenders cannot evade prosecution by merely suggesting that an image is not of a 'human' child, where they have tinkered with the image by adding non-human attributes, e.g. a tail. Last, it is not necessary that a person is identifiable: 'images of a child' also include images of 'an imaginary child. ${ }^{152}$ The age is a question of fact, though it remains unclear how a drawing or a cartoon of a 17-year-old will be distinguished from a drawing of an 18-yearold. ${ }^{53}$

\section{Defences}

Section 64 of the CAJA 2009 sets out general defences that mirror those available for the offences of possession of IIOC ${ }^{54}$ and EP images. ${ }^{55}$ The first covers those who can demonstrate that their legitimate business justifies possession of a PIOC, e.g. the police, prosecuting authorities, those dealing with complaints from the public about online content etc. ${ }^{56}$ The second relates to persons who had not seen the image and did not know, nor have reason to suspect that the images held were PIOC. This covers those who are in possession of offending images but are unaware of the nature of the images. Last, a person who was sent an unsolicited prohibited image and acted promptly, depending on the circumstances of the case, to delete it or otherwise dispose of it, has a defence.

Moreover, according to s 63 , 'excluded images, ${ }^{157}$ namely those contained in a classified work, ${ }^{58}$ will not fall foul of $s 62$. Similar to the EP offence, this exemption does not apply to images deliberately extracted from a classified work solely or principally for the purposes of sexual arousal, ${ }^{59}$ e.g. where a new video consisting of PIOC from classified works has been created. If it can reasonably be assumed that a certain part of a film was isolated for 
pornographic purposes, then upon removal the benefit of context can be lost and therefore, $s$ 63 does not apply. Consequently, the excerpt may be classed as prohibited. This is arguably in line with Murray, but the decision in the latter should be differentiated on the grounds that it related to the creation of a new image that focused on the genitals of the child, whereas $\mathrm{s}$ 63 contemplates that the exemption will not apply to footages as they appear in the original footage.

The Porter defence is applicable to cases involving this offence as well: Images that have been emptied from the 'Recycle Bin' may be considered to be within the control of a defendant who is skilled in the use of computers and owns the requisite software to retrieve such images. However, if a person cannot retrieve or gain access to them and had taken all reasonable steps to divest himself or herself of possession by placing them in the 'Recycle Bin' and emptying that, (s)he cannot be said to have custody or control of the images, notwithstanding the fact that these remain on the hard disk of a computer in his or her possession. ${ }^{60}$ The mental element required for the offence of possession to be made out in cases of deleted images is proof that the defendant 'did not believe that the image at issue was beyond his control. ${ }^{161}$ It will be a matter for the jury to determine in each case whether the images are beyond the defendant's control considering all particular circumstances, e.g. the defendant's computing skills and experience or how easily the images can be retrieved.

\section{PIOC vs. pseudo-photographs}

PIOC are distinguished from pseudo-photographs on the basis of how would the image at issue look like, if printed. If a high-quality computer-generated indecent image looked like a pseudo-photograph after it had been printed out, then it should be prosecuted under the PCA or CJA as such. ${ }^{62}$ As noted earlier, the 2009 Act specifically excludes pseudo-photographs from its ambit and therefore it may be inferred that an allegation that an image is, in fact, a pseudo-photograph could amount to a defence. The prosecution would bear the burden of proving to the ordinary criminal standard that the image at issue is not a pseudo-photograph.

\section{Provisions related to information society services}

Section 68 and Schedule 13 to the 2009 Act ensure that the provisions criminalising the possession of PIOC comply with the UK's obligations under the E-Commerce Directive. ${ }^{63}$ Providers of information society services established in the UK are covered by the new offence even when they operate in other states in the EEA. ${ }^{64}$ Schedule 13 limits the liability of Internet service providers in cases where they carry out activities necessary for the operation of the Internet; for instance, when they act as mere conduits for such material or store it as caches or hosts. ${ }^{65}$

\section{Possession}

The CAJA 2009 does not define 'possession.' However, as noted earlier, the offence under s 62 mirrors the position that exists for the offences of possession of EP images and IIOC under s 63 of the CJIA 2008 and s 160 of the CJA 1988 respectively. Accordingly, the same principles apply here as well.

The examination of the significant guidance provided by the Court of Appeal in Cheung ${ }^{66}$ will illuminate the issue of possession with respect to PIOC-related offences. In Cheung, the appellant, a Chinese national, was stopped by the police, who had seen him carrying a bulging laptop bag. Along with bundles of counterfeit DVDs, which gave rise to a separate charge, eight additional DVDs of pornographic nature relating to sexual activity with dogs were found underneath the mainstream counterfeit ones. The issue of whether those images fell within the statutory definition of extreme pornography under the CJIA was not contested at trial. In interview at the police station, Cheung admitted that he knew that the bag contained DVDs, which he was going to sell, but he had not looked at the DVDs and did not know that he possessed those of an EP nature. Cheung appealed against his conviction on seven counts of possessing EP images contrary to $s \quad 63$ on the basis that the trial judge had failed to give an adequate direction to the jury as to what the prosecution had to prove in respect of his knowledge. 


\section{Background}

Section 63 of the CJIA 2008 makes it is an offence to be in possession of an EP image, as defined in subsections (4), (5) and (6). Under section 65(1) of the 2008 Act, a person charged with an offence contrary to s 63 has a defence, if (s)he proves any of the matters mentioned in s 65(2). Among these matters are those specified in subsection (2)(b), namely that the person had not seen the image and did not know, nor had any cause to suspect, it to be an EP image. Section 65(2)(b) of the CJIA 2008 mirrors s 64(1)(b) of the CAJA 2009 (see table 1):

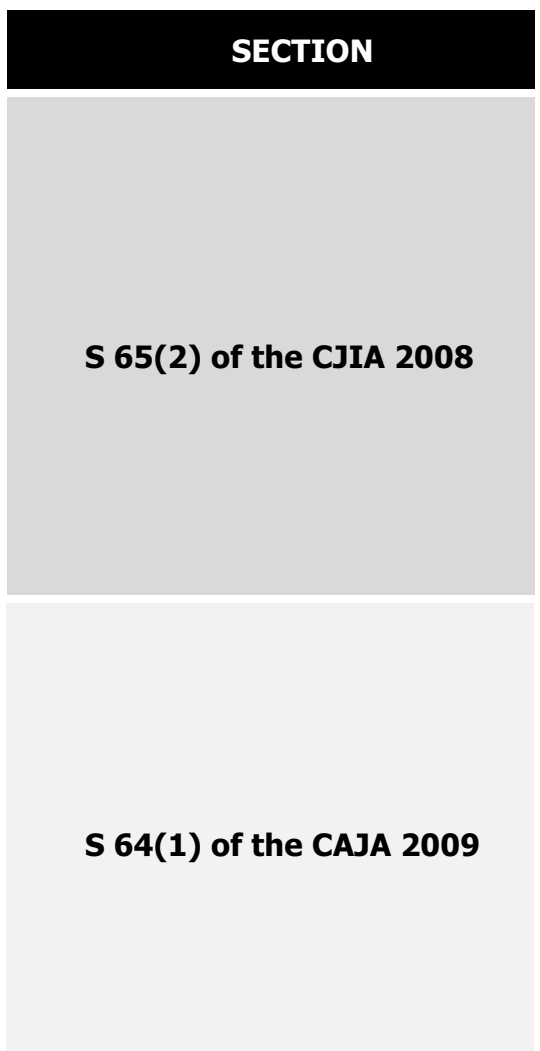

\section{DEFENCES}

Where a person is charged with an offence under $s 63$, it is a defence for the person to prove any of the matters mentioned in s 65(2). These are:

a) that he had a legitimate reason for being in possession of the image concerned; or

b) that he had not seen the image concerned and did not know, nor had any cause to suspect, it to be an extreme pornographic image;

c) that the person was sent the image concerned without any prior request having been made by or on behalf of the person and did not keep it for an unreasonable time.

Where a person is charged with an offence under s 62 , it is a defence for the person to prove any of the following matters:

a) that the person had a legitimate reason for being in possession of the image concerned;

b) that the person had not seen the image concerned and did not know, nor had any cause to suspect, it to be a prohibited image of a child;

c) that the person was sent the image concerned without any prior request having been made by or on behalf of the person and did not keep it for an unreasonable time.

\section{Table 1: Defences for the offences of possession of EP images and PIOC}

Before the statutory defence under s 65(2) became relevant, the prosecution had to establish that:

- 1. the appellant was in possession of the offending images, in the sense that they were within his custody or control in the bag he was carrying (physical possession); and

- 2. the appellant knew of the existence of the 'things' that were in his custody or control (mental possession).

However, the prosecution did not have to prove that Cheung knew that the 'things,' which were to his knowledge in his custody or control, had the necessary quality giving rise to the offence; for the present purposes, that the DVDs contained EP images. 'Otherwise, the defence under s 65(2)(b) would be otiose, ${ }^{167}$ King J stated.

Further clarification may be provided by Collier $^{68}{ }^{68}$ where the defendant possessed videotapes and CD-ROMs containing both adult pornography and IIOC. Collier was charged with possession contrary to $s 160$ of the CJA 1988 and maintained that although he had cause to suspect that the material contained indecent photographs, he had no reason to suspect that these were of children. The Court of Appeal held that the trial judge had erred in ruling that Collier could not rely on $s$ 160(2)(b), because he had cause to suspect that the images were indecent. Allowing the appeal, the Court ruled that the prosecution had to prove that the defendant knew he had the video-tapes and CD ROMs containing images. ${ }^{69}$ Namely, 
the only mens rea that the prosecution had to show was that the person knowingly possessed the image; not that the person knew that the image was, or was likely to be, an image of a child. The defendant would then have to rely on the defences under s 160(2)(b) and prove that (s)he had not seen the image in question and did not know, nor had any reason to suspect that the image was an indecent image of a child under 18. If the prosecution had to prove that the defendant knew that the videos or the CD-ROMs contained or were likely to contain indecent photographs of a child, then the statutory defence would never apply. ${ }^{70}$

Coming back to Cheung, the Court of Appeal added that:

it is only if there is a real doubt as to whether the defendant believed that that which he knew he had, was of a wholly different nature from that which in fact it was, that possession would not be made out. [...] A belief, for example, that something which is in fact a collection of DVDs is a collection of, say, floor files, might well qualify. ${ }^{71}$

Ignorance of, or a mere mistake as to the quality of the 'things' which the defendant knew were in his control could not excuse his liability. ${ }^{72}$ The Court of Appeal differentiated between knowledge in requisite mens rea and the specific statutory defence available to the offence of possession of EP images.

It was not necessary for the Crown to establish that the appellant knew of the exact nature of the eight DVDs at the bottom of the bag. It was sufficient that these were among the DVDs which he knew he had as a generality. ${ }^{73}$

Namely, the Court distinguished what had to be proved by the Crown for the purposes of possession, by way of knowledge on the part of Cheung prior to his bag being searched by the police from what had to be proved by Cheung by way of lack of knowledge to make out his statutory defence.

Therefore, for the purposes of establishing the offence of possession of a PIOC contrary to s 62 of the CAJA 2009, the Crown must show that the item in question was in the custody of the defendant or subject to his or her control. The only mental element that must be proved by the prosecution is that the defendant knew that (s)he was in possession of something which was, in fact, a PIOC (whether the defendant knew it was a PIOC or not). Nevertheless, proof of physical and mental possession will not necessarily result in a conviction. After possession has been established, the burden shifts to the defendant to prove on the balance of probabilities any of the matters in s 64(1) of the 2009 Act.

\section{Three years on: prosecutions and convictions}

The Home Office envisaged that the number of prosecutions for simple possession of PIOC alone would be 'extremely low. ${ }^{174}$ But if the offence is not frequently utilized, then how will the alleged harm caused by the possession of such material be tackled? What does this expectation suggest about the necessity of the measure? The anticipated infrequent use of the provisions defeats the claim that they constitute an effective response to the stated 'pressing social need"75 that justified the introduction of this offence. According to CPS records, the number of PIOC offences that reached at least one hearing in the magistrates' courts in 2011-12 is approximately nine times higher than that of the previous year: 


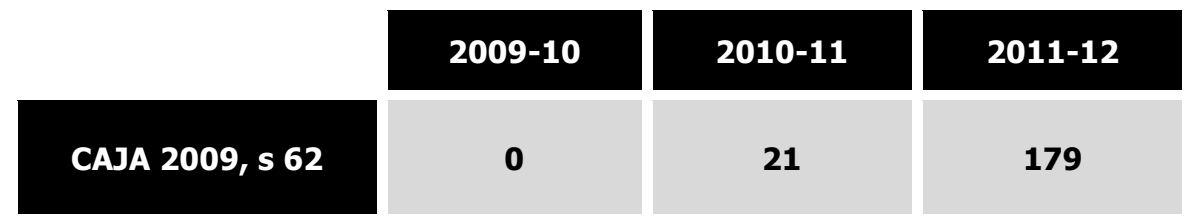

Table 2: Number of offences that reached at least one hearing in magistrates' courts $^{76}$

Research into the enforcement of this new offence is therefore required in order to ascertain whether or not it is misused or misunderstood.

Notwithstanding the fact that a relatively high number of PIOC offences were charged since the offence came into force in April 2010, according to the Ministry of Justice (MOJ), there were no convictions in that year, whereas only six offenders were found guilty at all courts in England and Wales in 2011. ${ }^{77}$ It should be noted that the figures obtained from the MOJ refer to calendar years, whereas the CPS figures (table 2) refer to financial years. In addition, the MOJ data indicate the number of defendants convicted at all courts in England and Wales, whereas the CPS data are not held by defendant: They show the number of offences that reached a hearing and give no indication of final outcome. ${ }^{78}$ Thus, a direct comparison between these prosecution and conviction rates is unsafe and consequently, the extent of the successful enforcement of the new offence is masked.

\section{An overbroad offence}

The two main arguments employed to justify the criminalisation of PIOC were: first, that PIOC may be used as grooming tools ${ }^{79}$ and second, that such material can 'fuel abuse of real children by reinforcing potential abusers' inappropriate feelings towards children. ${ }^{80}$ However, the then Government was unaware of any specific research into the link between accessing fantasy images of child sexual abuse and the perpetration of offences against children. ${ }^{81}$ No attempt was made to measure that link and no evidence was provided to suggest that groomers use PIOC alone to groom. ${ }^{82}$ A further argument advanced whilst the Coroners and Justice Bill (CAJB) was going through its parliamentary stages was that allowing the possession of PIOC encourages acceptance of such representations of children and serves to legitimise sexually abusive behaviour in abusers' minds. ${ }^{83}$ This argument supports perhaps the criminalisation of all PIOC, including fantasy images portraying imaginary children, but as Ost claims,

it provides a more justifiable basis for prohibiting the creation and distribution of [PIOC], given that those who possess [PIOC] do not propagate harmful attitudes. It is extremely difficult to find a legitimate basis for criminalising the possession of fantasy [PIOC] through a reasoned application of the harm principle. ${ }^{84}$

The author goes on to express her concern that, as public condemnation of such material entrenches ${ }^{85}$ using legal moralism as the basis for criminalisation provides legislature with broad law-making powers that are likely to lead to the creation of further offences. ${ }^{86}$ Ost proved to be right. In September 2012, Sir Paul Beresford, Conservative MP for Mole Valley, introduced under the Ten Minute Rule the Coroners and Justice (Amendment) Bill proposing the modification of s 62 to apply additionally to the possession of 'prohibited written material about a child'87 that 'fuels the phantasies of pedophiles which is the key factor in their offending behaviour. ${ }^{\prime 88}$ The Bill received its second reading in October 2012, but it ultimately failed to complete its passage through Parliament before the end of the session and will therefore make no further progress for the time being. Had it been passed, it would have constituted an unnecessary and unjustified extension of the offence, especially because the sphere of the material that may fall within s 62 is already overbroad. I shall now turn to discuss this in greater detail.

In the Consultation Paper that preceded the introduction of the offence, the Government of the day highlighted the problem of digital manipulation of images of real sexual abuse into 
a drawing or cartoon format through the use of special software. ${ }^{89}$ Its effect is that an image appearing to be a fantasy cartoon, would actually be a distinct record of an unlawful act. This problem is addressed by $\mathrm{s} 62$. The harm-based justification for the criminalisation of real IIOC equally applies to this particular case of PIOC. Additionally, as discussed earlier, children suffer psychological harm as a result of their knowledge that others view the records of their sexual abuse. ${ }^{90}$ Depending on the extent to which a child is recognisable from his or her manipulated portrayal, the same justification accounts quite persuasively for the prohibition of such PIOC. So, what attracts criminal penalty under s 62 in the case of a manipulated image of real child sexual abuse is an image which is not itself photographic, but is derived from a photograph or pseudo-photograph. However, the pre-existing law already covered such images. The CJIA $2008^{91}$ extended the scope of the IIOC provisions by amending the meaning of a 'photograph' ${ }^{\prime 2}$ to include, not just indecent photographs and pseudophotographs themselves, but also derivatives of them. The latter are tracings or other forms of data that are not in themselves photographs or pseudo-photographs but are derived from the whole or part of a photograph or pseudo-photograph or a combination of either or both. ${ }^{93}$ These derivatives include:

- 1. line-traced images, i.e. pencil-traced images using tracing paper; and

- 2. computer-traced images, i.e. photographs electronically converted into different kinds of 'art' through scanner or graphic manipulation packages. ${ }^{94}$

What the pre-existing provisions did not cover was the possession of free-hand drawings depicting real sexual abuse of a child by an adult, which were not the derivatives of a photograph or pseudo-photograph. This is where the legislative gap was. Nevertheless, this is not the main material targeted by the CAJA 2009. The then Government took one step further by introducing far-reaching provisions that criminalise fabricated images as well.

Moreover, in its guidance, the MOJ states that $\mathrm{s} 62$ merely criminalises the possession of material which was already illegal to publish under the OPA 1959..$^{95}$ Although this assurance ostensibly clarifies the scope of the offence, it is submitted that it complicates it instead. Under the 1959 Act, an article is deemed 'obscene,' if it tends 'to deprave and corrupt ${ }^{\prime 96}$ its likely audience. However, under the CAJA 2009, an image may be found by the jury to be 'disgusting' under s 62(2)(c) and therefore a prohibited one, without necessarily having any tendency 'to deprave and corrupt.' In addition, disgust is not synonymous with depravity and corruption. On the contrary, revulsion is a defence to an obscenity charge. ${ }^{97}$ Therefore, the images caught by the CAJA 2009 are not limited to those which are covered by the 1959 Act. In fact, there might be instances where the two Acts do not overlap. Hence, the scope of the offence under $\mathrm{s} 62$ is much wider.

Last, the offence under the CAJA 2009 raises serious concerns over its potential human rights implications. When the CAJB was going through its parliamentary stages, the Human Rights Joint Committee underlined the subjectivity of the offence and expressed doubts as to whether its definition was sufficiently precise and foreseeable to meet the requirement that any interference with Articles 8 and 10 of the European Convention on Human Rights (ECHR) be 'in accordance with the law.' The Committee also criticised the then Government's failure to sufficiently explain why the offence was necessary to meet the aims advanced and how it was proportionate to these. ${ }^{98}$

\section{Limiting the scope of the offence}

The CAJA provisions could be amended by limiting the scope of the offence to PIOC that depict real sexual abuse of real children. In practice, this would make it difficult, if not impossible, for prosecutors to identify cases where PIOC portray actual harm to real victims and therefore, render the offence under s 62 unworkable. However, a defence could be made available to those defendants who are able to establish that a non-photographic image was fabricated. This would entail the imposition of a legal burden onto the defendant, requiring him or her to establish that the PIOC in question did not feature a real child or real child sexual abuse. The reverse burden of proof is discharged by proof on the balance of probabilities. ${ }^{99} \mathrm{~A}$ defendant could testify as to the origin of the image, by explaining for instance how the image was created or by demonstrating his or her skill in digitally 
manipulating computer-generated images. An expert could provide evidence on the defendant's skill as well. Imposing an evidential burden upon the defendant would not eliminate the practical difficulty with which the prosecution would be faced, as once the defendant has satisfied this, the prosecution bears the legal burden of disproving the defence.

It is arguable that placing the legal burden on the accused violates Article $6(2)$ of the ECHR (presumption of innocence). However, a reverse onus provision does not inevitably give rise to a finding of incompatibility. The Strasbourg case law suggests that Art 6(2) does not create an absolute and unqualified rule ${ }^{100}$ and therefore limited inroads on the presumption of innocence may be justified. In order for such a limitation of the right under Article 6(2) to be acceptable, the test that needs to be met is whether it pursues a legitimate aim and satisfies the principle of proportionality. ${ }^{101}$ Placing the burden of proof on the defendant regarding the issue of whether the image is fabricated reframes the offence of possession of PIOC to serve the legitimate aim of avoiding real harm to real children. The principle of proportionality is also observed: While the reverse onus provision would require the defendant to prove matters that could exculpate him or her, the prosecution retains the responsibility for proving possession and the essential elements of the offence discussed above. In Att Gen of Hong Kong v Lee Kwong-Kut; Att Gen of Hong Kong v Lo Chak Man, the Privy Council held that exceptions from the strict application of the fundamental rule that throughout the trial it is for prosecution to prove the guilt of the defendant beyond reasonable doubt are permissible, provided that the prosecution retains primary responsibility for showing the important elements of the offence, as identified from the substance and reality of the statutory language..$^{102}$

\section{Concluding remarks}

Harm can be caused to children by PIOC that portray either real child sexual abuse or the fantasy sexual abuse of a real, recognisable child. ${ }^{103}$ However, s 62 of the CAJA 2009 covers all kinds of fantasy visual representations of child sexual abuse in the form of computergenerated images, cartoons or drawings. Criminalising what are effectively comics or fantasies constitutes a step too far from the liberal harm-based rationale that underpins the prohibition of images, which are records of real child sexual abuse. While any pornographic representation in which participants have not provided an informed and valid consent is a legitimate subject of criminal law, this offence may criminalise those who cause no harm to others by their actions and detract attention from tackling the circulation of IIOC, in which minors are victimised. Narrowing the scope of the offence by amending the 2009 Act to include a defence for fabricated images, first, would address the difficulty with which the Crown would carry the burden of proving that a PIOC depicts actual abuse of a real victim; second, it constitutes a proportionate encroachment on the presumption of innocence and third, allows for a reasonable freedom of thought and expression. ${ }^{104}$

\footnotetext{
* The City Law School, City University London, e: Alex.Antoniou.1@city.ac.uk

${ }^{1}$ The PCA 1978, ss. 1 and 6 as amended by the Criminal Justice and Public Order (CJPO) Act 1994, s. 84.

2 The PCA 1978, s. 6(2) as amended by the Criminal Justice and Court Services (CJCS) Act 2000, s. 41(1).

3 The CJA 1988, s. 160 as amended by the CJPO Act 1994, s. 84(4).

${ }^{4}$ The CJA 1988, s. $160(2 \mathrm{~A})$ as amended by the CJCS Act 2000, s. 41(3).

${ }^{5}$ The PCA 1978, s. 7(2) states that references to an indecent photograph include 'an indecent film, a copy of an indecent photograph or film, and an indecent photograph comprised in a film.'

${ }^{6} R$ v Land [1998] 1 Cr App R 301 at 305 (Judge LJ).

${ }^{7}$ R. Stone, 'Extending the Labyrinth: Part VII of the Criminal Justice and Public Order Act 1994' (1995) 58(3) MLR 386 at 389.

${ }^{8}$ A. Millwood Hargrave and S. Livingstone, Harm and Offence in Media Content: A Review of the Evidence, 2nd edn (Intellect Books: Bristol, 2009) 115.

${ }^{9}$ M. Bourke and A. Hernandez, 'The "Butner Study" Redux: A Report of the Incidence of Hands-on Child Victimization by Child Pornography Offenders' (2009) 24(3) Journal of Family Violence 183 at 183 (emphasis in the original).
} 
${ }^{10}$ Child Exploitation and Online Protection Centre, A Picture of Abuse: $A$ thematic assessment of the risk of contact child sexual abuse posed by those who possess indecent images of children, Executive Summary (CEOP: London, 2012) para. 23.

${ }^{11} R$ v Beaney [2004] EWCA Crim 449 at para. 9 (Keith J).

12 The PCA 1978 , s. 7(6) originally described a child as a person under the age of 16 . However, the Sexual Offences Act (SOA) 2003, s. 45(2) amended the 1978 Act by raising the age limit to 18 . The same change applies to the CJA 1988 by virtue of s 160(4). See A. Gillespie, 'The SOA 2003: (3)

Tinkering with "child pornography"' [2004] Crim LR 361 for a discussion about whether this change is desirable or necessary.

${ }^{13} R$ v Owen (1988) $86 \mathrm{Cr}$ App R 291 at 296 (Stocker L)).

14 The PCA 1978, s. 2(3).

${ }^{15}$ See Land, above n. 6.

${ }^{16} R$ v Graham-Kerr [1988] 1 WLR 1098 at 1106 (Stocker L]); $R$ v Smethurst [2002] 1 Cr App R 6 at para. 21 (Lord Woolf CJ).

${ }_{17} R$ v Stamford (1972) $56 \mathrm{Cr}$ App R 398 at 405 (Ashworth J).

${ }^{18}$ The circumstances and the taker's motivation can be relevant to the taker's mens rea as to whether his or her taking was intentional or accidental; see Graham-Kerr, above n. 16.

${ }^{19}$ See Smethurst, above n. 16 at para. 22 (Lord Woolf CJ); see further the case comment by D.

Ormerod and C. Barsby, 'Indecent photographs of children: making an indecent photograph of a child whether breach of ECHR, Art 8 and 10' [2001] Crim LR 657.

${ }^{20}$ The CJPO Act 1994, s. 84(2)(a); see $R$ v Bowden [2000] 1 Cr App R 438.

${ }^{21}$ Ibid. s. 84(3)(b); the same applies to the CJA 1988 by virtue of CJA 1988, s 160(4).

22 Ibid. s. $84(3)$ (c).

23 Ibid. s. 84(4).

${ }^{24}$ E. Renold and S. J. Creighton with C. Atkinson and J. Carr, Images of Abuse: A review of the evidence on child pornography, Summary of research and findings (NSPCC: London, 2003) 3

<http://www.nspcc.org.uk/Inform/publications/downloads/imagesofabuse_wdf48065.pdf> accessed 12 June 2013.

${ }^{25}$ Y. Akdeniz, Internet Child Pornography and the Law: National and International Responses (Ashgate Publishing Ltd: Aldershot, 2008) 22.

${ }^{26}$ See Land, above n. 6 at 305 (Judge LJ).

${ }^{27}$ The SOA 2003, s. 45(3) and s. 45(4) in combination with the PCA 1978, s. 1A and the CJA 1988, s. $160 \mathrm{~A}$.

28 The Coroners and Justice Act 2009, s 69.

${ }^{29}$ Obscenity and indecency are 'different steps on the scale of impropriety,' with obscenity being 'the graver of the two'; see Stamford, (1972) 56 Cr App R 398 at 405 (Ashworth J).

${ }^{30}$ Home Office, Consultation on Possession of Non-photographic Visual Depictions of Child Sexual Abuse (Home Office: London, 2007).

${ }^{31}$ Ibid. at $1,3$.

32 HC Deb 26 January 2009, vol 487, col 35 (Jack Straw, Secretary of State).

33 The CAJA 2009, s. 65(2).

34 Ibid. s. 65(3).

${ }^{35}$ Ibid. s. 62(9).

${ }^{36}$ On summary conviction, the maximum penalty is six months' imprisonment or a fine not exceeding the statutory maximum $(£ 5,000)$ or both. On conviction on indictment, the maximum penalty is three years' imprisonment or a fine (unlimited) or both; ibid. s. 66 and Sch. 22, para. 12.

37 See Home Office, above n. 30 at 9.

38 The SOA 2003, s. 80 and Sch. 3 to the Act, para. 35B.

${ }^{39}$ See Graham-Kerr, above n. 16 at 1106 (Stocker LJ); Smethurst, above n. 16 at para. 21 (Lord Woolf C]).

40 The CJIA 2008, s. 63(3) and s. 63(6)(b).

41 The CAJA 2009, s. 62(3).

42 Ibid. Explanatory Notes, para. 364.

43 Ministry of Justice (MOJ) Criminal Law Policy Unit, Circular 2010/06, Coroners and Justice Act 2009 (19 March 2010) at 22.

44 The CAJA 2009, s, 62(4) and s. 62(5); MOJ Circular 2010/06, ibid. at para. 17.

${ }^{45}$ An IIOC includes a film; the PCA 1978, s. 7(2).

${ }^{46} R$ v Murray [2004] EWCA Crim 2211 at para. 6 (Lord Justice Latham).

47 The CAJA 2009, s. 62(2)(c).

${ }^{48}$ See Home Office, above n. 30 at 7.

${ }^{49}$ See MOJ Circular 2010/06, above n. 43 at para. 18.

50 The CAJA 2009, s. 65(5).

51 Ibid. s. 65(6). 
52 Ibid. s. $65(8)$.

${ }^{53}$ Cf. Land, above n. 6; in relation to IIOC, expert evidence as to the matter of age is not admissible and the same principle is expected to apply here as well.

${ }^{54}$ The CJA 1988, s. 160(2).

55 The CJIA 2008, s. 65(2).

${ }^{56}$ For further guidance as to the 'legitimate reason' defence, see Atkins v DPP; Goodland v DPP [2000]

2 Cr App R 248 at 256, 257 (Brown LJ).

57 The CAJA 2009, s. 63(1), s. 63(2) and s. 63(5).

${ }^{58}$ Defined as a video work in respect of which a classification certificate has been issued by a designated authority; ibid. s. 63(7).

${ }^{59}$ Ibid. s. 63(3); cf. the CJIA 2008, s 64(3).

${ }^{60} R$ v Porter [2006] 2 Cr App R 25.

${ }^{61}$ Ibid. at para. 26 (Dyson LJ).

${ }^{62}$ CPS Legal Guidance, Indecent photographs of children

<http://www.cps.gov.uk/legal/h_to_k/indecent_photographs_of_children/\#a25> accessed 29 March 2013.

63 The E-Commerce Directive was implemented by the Electronic (EC Directive) Regulations 2002 (SI 2002/2013).

${ }^{64}$ Service providers established in an EEA state other than the UK are excluded from prosecution for the offence of possession of PIOC; the CAJA 2009, Sch. 13, para. 2.

${ }^{65}$ Ibid. Sch. 13, para. 3 to para. 5.

${ }^{66} R$ v Ping Chen Cheung [2009] EWCA Crim 2965 (CA, Crim Div).

67 Ibid. at para. 15 (King J).

${ }^{68} R$ v Collier [2005] $1 \mathrm{Cr}$ App $\mathrm{R} 9$.

${ }^{69}$ Ibid. at para. 20 (Hooper LJ); following Atkins, above s. 56 at 262 (Brown LJ).

70 Ibid. at para. 29 (Hooper LJ).

${ }^{71}$ See Cheung, above n. 66 at para. 15 (King J).

72 Ibid.

73 Ibid. at para. 17 (King J).

${ }^{74}$ See Home Office, above n. 30 at 9.

75 The Coroners and Justice Bill (CAJB) as introduced in the House of Commons on 14 January 2009, Explanatory Notes, para 859.

${ }^{76}$ CPS, Violence Against Women and Girls Crime (VAWG) Report 2011-12 (CPS: London, 2012) 52.

77 MOJ, Justice Statistics Analytical Services; Ref: 214-13, FOI 81446; the FOI request was made by the author and latest figures were received on 10 April 2013.

${ }^{78}$ See CPS VAWG, above n. 76 at 52, fn. 55.

${ }^{79}$ See Home Office, above n. 30 at 5.

80 Ibid. at 6.

81 Ibid.

82 By contrast, for the support of the EP provisions the Government of the day produced after the first reading of the Criminal Justice and Immigration Bill the Rapid Evidence Assessment, which was commissioned by the Department of Health; see C. Itzin, A. Taket and L. Kelly, 'The Evidence of Harm to Adults Relating to Exposure to Extreme Pornographic Material: A Rapid Evidence Assessment (REA)' MOJ Research Series 11/07 (MOJ: London, 2007); for a criticism of the research results, see F. Attwood and C. Smith, 'Extreme concern: regulating "dangerous pictures" in the United Kingdom' (2010) 37(1) J Law \& Soc 171.

${ }^{83}$ See the CAJB, Explanatory Notes, above n. 75 at para. 861; NSPCC, NSPCC Briefing: CAJB (2nd Reading, 26 January 2009) at 3

<http://www.nspcc.org.uk/Inform/policyandpublicaffairs/Westminster/briefings/CoronersandJustice_wdf 63084.pdf> accessed 1 April 2013.

${ }^{84}$ S. Ost, 'Criminalising Fabricated Images of Child Pornography: A Matter of Harm or Morality?' (2010) 30(2) Legal Studies 230 at 256.

85 C. Greer, Sex Crime and the Media: Sex Offending and the Press in a Divided Society (Willan: Devon, 2003) ch 4; P. Jenkins, Beyond Tolerance: Child Pornography on the Internet (New York University Press: London, 2003) 12.

${ }^{86}$ See Ost, above n. 84 at 256.

${ }^{87}$ The Coroners and Justice (Amendment) Bill (HC Bill 68), ss. 1(2) and 1(3) as introduced for its first reading in the House of Commons on 12 September 2012.

${ }^{88}$ D. Hughes, 'MP seeks ban on written child porn,' Press Association (12 September 2012)

Parliamentary News.

${ }^{89}$ See Home Office, above n. 30 at 5.

90 See Beaney, above n. 11.

${ }^{91} \mathrm{~S} 68$. 
92 Both in the PCA 1978, s. 1 and CJA 1988, s. 160.

${ }^{93}$ The CJIA 2008, Explanatory Notes, para. 480.

${ }^{94}$ The offender takes a photograph and by using tracing paper traces its outlines and from there to a piece of paper. The tracing is coloured in and the original photograph subsequently destroyed. The same process can be followed by electronic means, such as by using a scanner and specific software or mobile phones with built-in effects that generate tracings rather than full photographs; see CPS Legal Guidance, above n. 62.

${ }^{95}$ See MOJ Circular 2010/06, above n. 43 at para. 19.

${ }^{96}$ The OPA 1959, s. 1(1).

${ }^{97} R v$ Calder and Boyars [1969] 1 QB 151, 169 (Salmon LJ): the 'aversion defence.'

${ }^{98}$ Joint Committee on Human Rights, Legislative Scrutiny: CAJB, Eight Report of Session 2008-9 (TSO: London, 2009) para. 1.172.

${ }^{99} R \vee$ Dunbar [1958] 1 QB 1, CCA.

100 Salabiaku v France (Appl No 10519/83) (1991) 13 EHRR 379 at para. 28.

${ }^{101} R$ v Lambert [2002] 2 AC 545 at 588 (Lord Hope of Graighead).

102 [1993] AC 951 at 969 (Lord Woolf).

103 Ost, above n. 84 at 255.

${ }^{104}$ S. Guest, 'Respect for Bad Thoughts' (2008) UCL Human Rights Review 118; S. Friel, 'An Alternative to Regulating "Victimless" Computer-Generated Child Pornography' (1997) 32(1) Valparaiso University Law Review 207 at 260. 